УДК $371.001 .76(477)$

DOI:

Ольга Кобрій, доктор педагогічних наук, професор кафедри загальної педагогіки та дошкільної освіти Дрогобицького державного педагогічного університету імені Івана Франка Галина Ренчка, вчитель Кимирської загальноосвітньої школи I - II ступеня Перемишлянського району Львівської області

\title{
ПЕДАГОГІЧНІ УМОВИ ДОСЯГНЕННЯ САМОВИЗНАЧЕННЯ ТА САМОРЕАЛІЗАЦІЇ ОСОБИСТОСТІ
}

У статті обтрунтовується необхідність розкриття педагогічних умов досягнення особистістю самовизначення та самореалізачиї задля реформування змісту освіти. Вони стосуються забезпечення його індивідуалізачії, проблемності, досвіду творчої діяльності, зменшення частки засвоюваної інформації, акценту на самостійній роботі учнів, а також демократизаиії стосунків з ними, прикладу педагога, його моральної позииіï.

Ключові слова: педагогічні умови; самовизначення; самореалізація; зміст освіти; індивідуалізація; проблемність; досвід творчої діяльності; самостійна робота; демократизаиія стосунків.

Jim. 11.

Olha Kobriy, Doctor of Sciences (Pedagogy), Professor of the General Pedagogy and Pre-School Education Department Drohobych Ivan Franko State Pedagogical University

Halyna Renchka, Teacher of Kymyr Secondary School of Peremyshlyany district, Lviv region

\section{PEDAGOGICAL CONDITIONS OF ACHIEVING SELF-IDENTIFICATION AND SELF- FULFILLMENT OF PERSONALITY}

The article substantiates the necessity of disclosing the pedagogical conditions of achieving the true personality self-identification and self-fulfillment for the purpose of reforming the content of education. They are related to ensuring its individualization, problem-solving character, experience of creative activity, reduction of the share of information to be acquired, emphasis on student independent work, as well as democratization of relations with them, the role of a teacher, his moral position.

Since the main reference point for restructuring the content of Ukrainian education is orientation towards the spiritual and emotional spheres in the structure of personality, then manifestation of genuine humanization of this content is focusing on urgent and perspective interests of the child, creating conditions for individualization and differentiation of the educational process.

Adaptation to the conditions of entry of the younger generation into an open society and ensuring their selfidentification and self-fulfillment requires such updating of the content of education which leads to a reduction in the share of information to be mastered and increase in the knowledge about ways of learning, the ability to process and use information for individual development, as well as the share of personal experience in creative activity. Only the problem-solving situations and setting problems to be solved specifically for each person give them the opportunity to engage in research work and to strain intelligence, social or physical spheres of life.

The personality self-identification and social development require the implementation of an individual approach to the child, without which it is impossible to democratize the educational process. The individual work with personality involves such interaction with a person that corresponds to the specifics of his/her inner world and the technique of self-improvement. At the same time, independent activity of personality is a precondition for one's formation as an agent of democratic relationships.

Keywords: pedagogical conditions; self-identification; self-fulfillment; a content of education; individualization; a problem-solving character; experience of creative activity; an independent work; democratization of relationships.

$\Pi$ остановка проблеми. Перебіг багатьох перетворень у сучасній педагогічній освіті обумовлюються в межах виховання активності, самостійності, уваги до індивідуалізації навчання, міжпредметних і внутріпредметних зв'язків у навчальному матеріалі тощо. Тенденція демократизації, що виявляється упристосуванні інформації до потреб особистості та умов майбутньої діяльності, передбачає забезпечення розвитку кожної особистості шляхом створення можливостей для самостійного вивчення предмету, через велику увагу до розв'язування задач тощо.

Аналіз досягнень 3 проблеми. Питання перебудови змісту сучасної освіти висвітлювали педагоги I. Бех [1] (стосовно особистісно 
зорієнтованого підходу в освіті), О. Вишневський [2], О. Корсакова [5], С. Трубачова [5] (які захищають ідею організації перетворювальної діяльності у навчанні), О. Глузман, І. Богданова (щодо тенденцій розвитку педагогічної освіти), Б. Степанишин, А. Фурман [9] (акцентують на необхідності розвитку особистості) та ін. Вони підкреслюють необхідність визначення змісту освіти у демократичному освітньому процесі, звертають увагу майбутніх фахівців на їхній компетентності, а не інформатизації, дають змогу домогтися певного розумного балансу між засвоєнням інформації і розвитком особистості у процесі самостійної роботи, однак не ставлять за мету з'ясувати сугність проблеми самовизначення та самореалізації особистості як чинника ㄲï соціального розвитку, не обгрунтовують необхідність розкриття педагогічних умов його формування.

Мета статті - 3'ясувати сутність проблеми самовизначення та самореалізації особистості як чинника іiї соціального розвитку і визначити педагогічні умови його формування у шкільній практиці.

Основний матеріал дослідження. Згідно 3 Національною доктриною розвитку освіти, важливими напрямами оновлення змісту освіти вважають: особистісна орієнтація всієї системи освіти, пріоритет загальнолюдських і національних цінностей, забезпечення якості освіти на основі новітніх досягнень науки, культури і соціальної практики. Передовсім вибір інформації (чи змісту завдань) забезпечить різнорівневий зміст освіти, який, як правило, відображений у різнорівневих підручниках, програмах, посібниках. Саме профільне навчання (навіть поглиблене вивчення предметів) уже створюватиме необхідні умови для демократичної побудови змісту освіти. Відтак усі предмети повинні забезпечувати якісну підготовку до повноцінної життєдіяльності в інформатизованому суспільстві, сприяти підвищенню ефективності освіти.

Зрозуміло, що найголовнішим орієнтиром перебудови змісту української освіти є орієнтація на духовну й емоційну сфери у структурі особистості, і виявом справжньої гуманізації цього змісту $\epsilon$ зосередження на актуальних i перспективних інтересах дитини, створення умов для індивідуалізації та диференціації освітнього процесу. Так, реалізація Концепції гуманітарного розвитку на період до 2020 року сприятиме “формуванню демократичного, консолідованого суспільства, де знання та можливості їх практичного застосування стануть важливим засобом самореалізації і розвитку особистості, i тим самим сталого розвитку держави” [4].
Поширення досвіду активізації педагогічної взаємодії вчителів та учнів (наприклад, із Липецька на початку 60-х pp. XX ст.) змушувало кращих учителів до інтенсивного поширення (закріплення, узагальнення) навчального матеріалу, гнучкості в організації занять, творчого підходу до побудови уроків. Досвід творчої роботи Василя Сухомлинського є повчальним прикладом успішного розв'язання важливих освітніх завдань, поставлених перед педагогами. Відчуття радості самостійної праці, за В. Сухомлинським, сприяє формуванню моральності, відрази до використання чужої праці $[8,245]$.

Зауважимо, що адаптація до умов входження молодого покоління у відкрите суспільство та забезпечення його самовизначення i самореалізації потребує такого осучаснення змісту освіти, що веде за собою зменшення частки інформації. що засвоюється, та зростання обсягу знань про способи пізнання, умінь переробляти й застосовувати інформацію для індивідуального розвитку, а також частки забезпечення особистого досвіду творчої діяльності [2, 112]. Адже інформація людині потрібна (для переходу до творчої діяльності), однак повинна відповідати індивідуальним запитам та інтересам, можливостям особистості й орієнтуватися на майбутнє (вона пропонується не для вивчення напам'ять, а для її використання у творчій роботі). Відтак нарощування потребує частка творчої діяльності, і зайва інформація (що не використовуватиметься у творчій діяльності, а $з$ часом забудеться чи відкинеться людиною) не пропонується.

Лише проблемні ситуації та постановка задачі конкретно для кожної особистості дають їй змогу включитися у пошукову чи дослідницьку роботу та напружити інтелект, соціальну чи фізичну сфери життєдіяльності, а також долати труднощі, тобто вдосконалюватися. У навчальних посібниках відповідно головне місце повинні займати задачі (різного рівня складності), а не готова інформація.

Самовизначення особистості та іiї соціальний розвиток потребують реалізації передовсім індивідуального підходу до дитини, без чого неможлива демократизація освітнього процесу, що також обгрунтовується у творчості В. Сухомлинського. Адже для всебічного розвитку особистості, вважав педагог, важлива потреба особистості працювати і до того ж самій, і питання організації пізнавальної діяльності розглядалося педагогом у нерозривному зв'язку із самостійною роботою учнів. Водночас педагог наголошував, що це має бути вільний вибір 
людини. На прикладі досвідчених вчителів Павлиської середньої школи підкреслюв, що домагатися цього треба доброю волею учнів, їх прагненням перевірити свої сили. До того ж, необхідність становлення яскравої індивідуальності підкреслювали також О. Дзерович, В. Пачовський та ін.

Як зазначає В. Храмова у передмові до твору М. Шлемкевича "Загублена українська людина”, відповідно до української ментальності серед українців спостерігається “індивідуальна форма цілепокладання й особиста відповідальність за наслідки ціле реалізації” $[11,5]$. На користь індивідуального в житті В. Храмова вважає, що, виникла необхідність негайного переосмислення “колективістського зрозуміння антропологічної конституції культурного світу, безумовного прийняття пріоритетності особистого, а не суспільного буття", і єдиним критерієм “культурності" соціуму вона бачить міру його гуманності, “ступінь орієнтації на ствердження індивідуального існування" [11, 11 - 12].

Індивідуальна робота 3 особистістю передбачає таку взаємодію з особистістю, яка відповідає специфіці її внутрішнього світу і методиці самовдосконалення, зорієнтованій на високий рівень готовності та здатності до співпереживання з особистістю, допомогу у пошуках, хвилюваннях і переживаннях, добру атмосферу спілкування. Самостійна діяльність кожної дитини чи дорослого $є$ основною передумовою становлення ії чи його як суб' єкта демократичних стосунків. Ї̈̈ ефективність визначається самоорганізацією, самоосвітою, саморозвитком. А результатом такої діяльності буде здатність справлятися із різними життєвими ситуаціями.

Представники реформаторської педагогіки вважали, що “піклування” як основа виховання не обмежується лише доглядом і захистом дитини, адже, готуючи молоде покоління до самостійної, творчої, практичної діяльності, старше покоління передає молодшим досвід, культурні надбання, звичаї, традиції. Результатом такої передачі $\epsilon$ формування у молоді певного світогляду, рис характеру, естетичного почуття, творчих здібностей, набутих знань, умінь, навичок тощо. У цьому зв'язку Е. Жарський ставив проблему спілкування як педагогічної взаємодії суб'єктів виховання, що має чітко визначену мету та узгодженість у діях. Як прихильник реформаторської педагогіки він зазначав, що “виховник є тільки посередником у процесі культуризації, він влегчує цей процес в точно визначених умовах і суспільних ситуаціях" $[3,5]$.
За В. Сухомлинським, активна діяльність, досягнення та усвідомлення істини $є$ результатом особистих зусиль дитини: “Щоденно, на кожному уроці учень повинен щось добувати власною працею" [6, 491], і треба допомогти кожному знайти себе, виявити себе в улюбленій праці, стати майстром - це, за В. Сухомлинським, альфа і омега виховання особистості й колективу [7, 566]. Педагог завжди говорив про важливість уміння спостерігати, думати, висловлювати власну думку [8, $99-100]$.

У контексті демократизації освітиВ. Сухомлинський пропонував завдання творчого характеру, що орієнтують на перетворювальну діяльність, звертав увагу на творчий характер перетворювальної діяльності у випадку здійснення самостійного перенесення знань у нову ситуацію. Велике значення він надавав дослідницькому характеру інтелектуальної праці, називав іiі перетворенням оточення. 3'ясування проблемних завдань, постановка задач дослідницького характеру фіксують зв'язок навчальних предметів із практикою, життям, що забезпечує успішну професійну діяльність у майбутньому та зобов' язує поєднувати у навчанні теоретичну роботу з практичною. До того ж, він уважав, що дослідницьким характером володіють три види праці: праця на навчально-дослідній ділянці, праця в майстерні і праця в лабораторії.

Відтак усі освітні установи повинні створювати відповідні умови та організовувати різні види праці. За О. Корсаковою, ці установи мають дбати про підготовку особистості до активного життя в суспільстві: “Провідними стають не засвоєння формальних знань і навичок, а гуманність стосунків, свобода самовиявлення, культивація індивідуальності, творча самореалізація особистості” $[5,4]$.

А. Фурман також акцентує увагу педагогів на проектно-пошуковій активності суб'єктів пізнання, наголошує, що є універсальним, на його думку, шляхом їх розв' язання, коли “знання стає власним здобутком” [9, 44], що супроводжується здогадками, сумнівами, увагою, емоціями, запитаннями, припущеннями тощо $[9,73]$. Відповідно, важливим показником активності та самостійності особистості $€$ “уміння узагальнювати, виділяти головне, застосовувати загальні закономірності для пояснення окремих фактів" [9, 135].

Невипадково й сьогодні якісне визначення змісту базової педагогічної підготовки. В. Шахов чітко пов'язує із включенням у підручники чи посібники творчих завдань “на аналіз, порівняння, узагальнення теоретичних положень, осмислення 
шкільної практики, пояснення й аргументацію своєї точки зору” $[10,104]$. Водночас педагог відзначає наявність завдань переважно репродуктивного чи репродуктивно-творчого характеру, які передбачають спостереження за педагогічним процесом, ознайомлення 3 досвідом роботи, складання планів тощо.

Самостійність є важливою особливістю діяльності суб' єкта уії реалізації. Суб' єкт діятиме як вільна особистість лише в позиції самостійної особистості. Тому ефективність дій суб'єкта залежить від особистого включення у діяльність, усвідомлення обмеженості наявних засобів, пошуку нових, і їі результатом буде здатність справлятися із різними життєвими ситуаціями, розвиток.

Виявлення прагнень до самовдосконалення i самореалізації, створення максимально сприятливих умов розвитку здібностей кожної людини, для їі самовизначення, подолання формалізму, досягнення високих результатів у особистісному розвитку і вихованні дозволяють приділяти більшу увагу індивідуальній роботі зі студентом, забезпечувати корекцію особистісного зростання кожного, пристосовувати організацію навчальної діяльності до його індивідуальних особливостей. Це $\epsilon$ свідченням усвідомлення значущості гуманістичних ідей задля збагачення власного досвіду, майбутнього професійного зростання.

Створення максимально сприятливих умов для виявлення і розвитку здібностей кожної людини, іiі самовизначення і самореалізації, подолання формалізму, стійкого небажання вчитися веде до необхідності духовного збагачення людини. Творче осмислення життєвого досвіду та зацікавлення успіхами дитини, стимулювання іiі наполегливості і працьовитості сприятиме реалізації гуманістичних стосунків педагога 3 учнями, допоможе навчитися великодушності, толерантності, терпимості, доброти, не проявляти безпринципність, слабохарактерність, а співіснувати з різними людьми та їх життєвими установками, відстоювати власні погляди.

Наші уявлення про саморозвиток, самореалізацію та самовиховання особистості у навчанні втілюють такі перспективи педагогічної освіти, які пов'язані також із постійним самостійним навчанням за допомогою мережі Інтернет. Це означає розповсюдження дистанційного навчання, зручних форм одержання освіти, застосування блочно-модульної технології, інтерактивних методів і засобів, більш індивідуалізованого навчання. Йдеться також про нормативно-правову базу для інноваційних процесів, різні засоби реалізації якісного вивчення навчальних предметів.

Вивільнення творчих сил людини, відхід від диктату, прагнення до ініціативної творчої праці допоможуть їй звільнитися від психології раба, позбутися споживацького ставлення до життя. Домінування раціоналізму насправді привело до втрати рівноваги в житті людини, ігнорування духовних цінностей, втрати гармонії у суспільстві та в кожній особистості. Лише усвідомлення християнських засад виховання допоможе духовному відродженню суспільства і освітніх закладів, гуманізації освітнього процесу.

Визначальна роль духовних цінностей узгоджується з вибором християнської філософії за основу сучасної української освіти. Водночас глибоке знання духовної спадщини, історії, мови народу, повага до витворів національної культури, шанобливе ставлення до культурних надбань інших націй забезпечують формування почуття гордості за свій народ допомагають усвідомити взаємозв'язок між націями, повагу до інших націй, загальнолюдські цінності. Тільки в рамках моральних цінностей можна дбати про добробут нації, працювати для добра свого краю і його свободи, брати на себе відповідальність за долю свого народу. В цьому полягає головна мета самовизначення і самореалізації особистості.

Особливістю становлення особистості в умовах свободи має стати забезпечення атмосфери довір'я до неї як істоти самовідповідальної, забезпечення можливостей для ¥іï самоконтролю, самоорієнтації, самовираження. Вироблення в людини власного "механізму" морального самоконтролю та самореалізації допоможе у забезпеченні переходу зовнішніх правил поведінки у “самопримус".

Висновки. Завдання дослідницького характеру, формування атмосфери зацікавленості, напруження розумових сил, долання труднощів у навчанні, розв'язування цікавих задач тощо сприяють розвитку мислення, великому успіху у навчанні, і шляхом організації самостійної роботи особистості, надання навчальному процесу творчого характеру, створення умов для переживання кожною дитиною радості праці і творчості тощо можна забезпечити ії повноцінний розвиток. Лише збільшення частки самостійної роботи учнів допомагає реалізувати демократичні перетворення в системі української освіти.

Педагогічними умовами досягнення людиною самовизначення та самореалізації. У шкільній практиці є забезпечення індивідуалізації, проблемності змісту освіти, зменшення частки засвоюваної інформації, акцент на самостійну 
роботу учнів, а також приклад педагога для наслідування, його чітка моральна позиція, демократизація стосунків з учнями, коли не нав'язуються погляди і переконання, не втручаються у поведінку, а дбайливо ставляться до оточуючих, поважають їхню гідність. Готовність до самоосвіти та громадянська відповідальність за своє навчання завжди будуть цінніми надбаннями особистості і займатимуть чільне місце у неперервній освіті.

Акцент у вихованні, відповідно до процесів гуманізації свідомості особистості, педагог переносить на повагу до людини, її прав, на становлення в ній людяності, формування іï духовного світу. Освітні заклади повинні утверджувати самоцінність людської особистості, увагу до ii iндивідуальних особливостей, забезпечувати виховання любові, милосердя до людей, працьовитості, гідності, наполегливості, ініціативності, творчості. Це означає також створення максимально сприятливих умов для виявлення і розвитку здібностей кожної людини, для іiї самовизначення і самореалізації, подолання формалізму, стійкого небажання дітей вчитися.

\section{ЛІТЕРАТУРА}

1. Бех І.Д. Особистісно зорієнтоване виховання: наук.-метод. посіб. Київ: ІЗМН, - 1998. - 204 с.

2. Вишневський О. Теоретичні основи сучасної української педагогіки: посіб.для студ. 2-е вид., доопрац. і доп. Дрогобич: Коло,- 2006.- 608 с.

3. Жарський Е. Виховання: суть, мета, курс працівників дошкілля: зб.матеріалів. Нью-Йорк: Шкільна Рада УККА, - 1967. - 33 с.

4. Концепція гуманітарного розвитку України від 27.03.2008 p. [Електронний ресурс]. Режим доступу: http: www.guon.kiev.ua/?q=node/446

5. Корсакова О., Трубачова С. Зміст сучасної шкільної освіти. Відкритий урок.-2006. - № 3-4. C. 3-11.

6. Сухомлинський В. Методика виховання колективу. Вибрані твори: у 5-ти т. Київ: Рад. школа, - 1977. Т. 1. - С. 403-637.

7. Сухомлинський В. Народження громадянина. Вибрані твори: у 5-ти т. Київ: Рад. школа, - 1977. T. 3.- C. 283-582.

8.Сухомлинський В. Проблеми виховання всебічно розвиненої особистості. Вибрані твори: у 5-ти т. Київ: Рад. школа,- 1976. Т. 1.- С. 55-206.

9. Фурман А. Теорія і практика розвивального підручника: монографія. Тернопіль: Економічна думка, - 2004. - 288 с.

10. Шахов В. Базова педагогічна освіта майбутнього вчителя: загальнопедагогічний аспект. Вінниця: Едельвейс, - 2007.- 383 с.
11. Шлемкевич М. Загублена українська людина. Київ: МП Фенікс,- 1992.- 158 с.

\section{REFERENCES}

1. Bekh, I. D. (1998). Osobystisno zoriientovane vykhovannia: nauk.-metod. posib. [Personally oriented education: science-method. manual]. Kyiv: IZMN, 204 p. [in Ukrainian].

2. Vyshnevskyi, O. (2006). Teoretychni osnovy suchasnoi ukrainskoi pedahohiky: posib.dlia stud. 2-e vyd., dooprats. i dop. [The theoretical Foundations of Modern Ukrainian Pedagogy]. Manual for students, the 2nd edition, modified and supplemented. Drohobych: Kolo, 608 p. [in Ukrainian].

3. Zharskyi, E. (1967). Vykhovannia: sut, meta, kurs pratsivnykiv doshkillia: zb.materialiv [Education: the essence, purpose, course of the employees of the elementary school: a collection of materials]. Niu-York: Shkilna Rada UKKA, 33 p. [in Ukrainian].

4. Kontseptsiia humanitarnoho rozvytku Ukrainy vid 27.03.2008 r. [The Concept of Humanitarian Development of Ukraine dated March 27, 2008]. [Electronic resource]. Available at: http: www.guon.kiev.ua/?q=node/446[in Ukrainian].

5. Korsakova, O. \& Trubachova, S. (2006). Zmist suchasnoi shkilnoi osvity [Content of modern school education]. Open lesson. No. 3-4,pp. 3-11. [in Ukrainian].

6. Sukhomlynskyi, V. (1977). Metodyka vykhovannia kolektyvu [Methodology of team upbringing]. Selected works in 5 volumes. Kyiv: Rad. shkola, Vol. 1, pp. 403-637. [in Ukrainian].

7. Sukhomlynskyi, V.(1977). [Narodzhennia hromadianyna Birth of a citizen]. Selected works in 5 volumes. Kyiv: Rad. shkola, Vol.3,pp. 283-582. [inUkrainian].

8. Sukhomlynskyi, V. (1976). Problemy vykhovannia vsebichno rozvynenoi osobystosti [The problems of education of all-round developed personality]. Selected works in 5 volumes. Kyiv: Rad. shkola, Vol. 1, pp. 55-206. [in Ukrainian].

9. Furman, A. (2004). Teoriia i praktyka rozvyvalnoho pidruchnyka [The theory and practice of developmental textbook]. Ternopil: Ekonomichna dumka, 288 p. [in Ukrainian].

10. Shakhov, V. (2007). Bazova pedahohichna osvita maibutnoho vchytelia: zahalnopedahohichnyi aspekt [Basic pedagogical education of the future teacher: general pedagogical aspect].Vinnytsia: Edelveis, 383 p. [in Ukrainian].

11. Shlemkevych, M. (1992). Zahublena ukrainska liudyna [The lost Ukrainian person]. Kyiv: MP Feniks, 158 p. [in Ukrainian].

Стаття надійшла до редакції 29.01.2019 